Page 520- 528 ISBN: 978-602-6 988-75-1

Web Jurnal Online: jurnal.unmuhjember.ac.id By: Endah Vestikowati; R. Rindu Garvera; Ii Sujai Sinergity Of The Village Private Business Agency (Bumdes) "Kupas Seirama" On The

Improvement Of Village Community Welfare

\title{
SINERGITY OF THE VILLAGE PRIVATE BUSINESS AGENCY (BUMDES) "KUPAS SEIRAMA" ON THE IMPROVEMENT OF VILLAGE COMMUNITY WELFARE
}

\author{
Endah Vestikowati, R. Rindu Garvera, Ii Sujai \\ Universitas Galuh \\ e-mail: vestiunigal@gmail.com
}

\begin{abstract}
The purpose of the study was to determine the existence of BUMDes in Pawindan Village in improving rural welfare. The era of autonomy has made the paradigm of the village community that development should start from the level of the "grassroots" community. This is supported by the Village Fund program which is a stimulator of infrastructure development and can also be a driver of the development of other sectors. One form of village development policy is the presence of Village-Owned Enterprises (BUMDes). But new problems emerged in Pawindan Village, which was dominated by the existence of pre-prosperous communities and dominated by less productive communities from the economic sector and community waste issues that had not been managed and organized properly. The method used is descriptive qualitative research with data analysis using data triangulation techniques. The results of the study show that the BUMDes "Kupas Seirama" shows that: (1) "Kupas Seirama" BUMDes are focused on integrated waste management and have high economic value; (2) "Kupas Seirama" BUMDes have become a driver in providing labor-based employment; (3) BUMDes "Kupas Seirama" has succeeded in increasing the village's original income.
\end{abstract}

Keywords: BUMDes Program, Kupas Seirama, Property, Village Community. 
Proceeding ICOGISS 2019

Page 520- 528 ISBN: 978-602-6 988-75-1

Web Jurnal Online: jurnal.unmuhjember.ac.id

By: Endah Vestikowati; R. Rindu Garvera; Ii Sujai

Sinergity Of The Village Private Business Agency (Bumdes) "Kupas Seirama" On The

Improvement Of Village Community Welfare

\section{INTRODUCTION}

Rural development is inseparable from the role of the Village Government, Village Devices, Village communities, and stakeholders who want progress and increased welfare. In addition, the role of the Central Government and Regional Government greatly contributed to the provision of a budget for the costs of implementing the Village Government program. The village also has the authority to regulate and manage the interests of the village community in accordance with established laws and aims to improve the welfare of the village community. Rural development is currently oriented towards development based on local wisdom and adapted to the socio-cultural characteristics of the local village community.One of the villages that has readiness in improving the welfare of the village community, namely the Pawindan Village. Pawindan Village is one of the villages in Ciamis Regency, West Java Province. The distance from the district government center is $5 \mathrm{~km}$, the distance from the city administration is $3 \mathrm{~km}$, while the distance from the provincial capital is $123 \mathrm{~km}$. for the boundaries of Pawindan Village are as follows:

a. Northside : Sindangrasa Village, Ciamis District.

b. East : Linggasari Village, Ciamis District.

c. South : Tasikmalaya Regency.

d. West : Panyingkiran Village, Ciamis District.

Pawindan Village Chief named Ahmad Kartoyo. Administratively Pawindan Village consists of 11 RWs which are divided into 26 Rt with an area of $21 \mathrm{Ha}$. Pawindan Village has a superior commodity of wetland rice based on planting area and based on economic value.The livelihoods of the people of Pawindan are varied, such as working as employees as many as 320 people, Civil Servants as many as 1010 people, TNI/Polri as many as 46 people, private sector/BUMN as many as 173 people, entrepreneurs/traders as many as 228 people, farmers as many as 15 people, farm workers as many as 51 people. There are also 2 people working in the service sector, 64 retirees, and 3,015 working in other fields and 1,031 unemployed/unemployed people. There are 1,368 families in Pawindan Village, 275 Pre-Prosperous Families, 1,150 Families of Prosperous Families and III Plus 102 Family Welfare Families. For the education level of the Pawindan Village community, it can be said that it is still very low because there are still many people who are educated only up to 1,683 elementary school graduates. Middle school/equivalent graduates as many as 710 people, high school graduates/equivalent as many as 707 people. There were also people who went on to go to Higher Education, namely 79 Academy/D1-D3 graduates, 134 S1 graduates, and 7 Masters graduates. Whereas for those who do not receive education, there is absolutely nothing. Institutions at the pawindan village level include the Community Empowerment Institution (LPM) with 35 administrators with 3 types of activities. The village PKK driving team (TPPKK Desa) with a total of 35 people with a total of 30 types of activities. Karang Taruna with a total of 5 people and a total of 3 types of activities. BUMDesa with 13 administrators with 6 activity units, RW with 11 and RT as many as 26 . 
Page 520- 528 ISBN: 978-602-6 988-75-1

Web Jurnal Online: jurnal.unmuhjember.ac.id

By: Endah Vestikowati; R. Rindu Garvera; Ii Sujai

Sinergity Of The Village Private Business Agency (Bumdes) "Kupas Seirama" On The

Improvement Of Village Community Welfare

\section{INDICATORS OF PRE-PROSPEROUS COMMUNITIES}

Basically family is something that is very vital for our lives. Without family, we will not be able to know well about social interactions, caring, and affection. Because families are social agents who are able to provide and teach about socialization. Many things that make families not functioning properly in social life, one of which is improper socialization or imperfect socialization is the existence of economic problems that are their main focus. The inability to meet the basic needs of each member of the family is the main reason for pre-prosperous families. The main characteristics of a pre-prosperous family are the inability to fulfill family needs, including:

a. Not able to meet basic needs;

b. Not able to reach health services;

c. The floor of the house is land; and

d. Lack of education for all family members.

\section{PROFILE OF BUMDES KUPAS SEIRAMA}

Village development can be carried out starting from small devices such as families to the most macro units in the form of Business Units. One form of village development policy, namely through Village-Owned Enterprises (BUMDes). With the existence of these BUMDes, it is expected to contribute to the increase of Village Original Income (PADes), so that the existence of these BUMDes can be felt by all villagers. One of the BUMDes that exists in an effort to improve the welfare of rural communities, namely BUMDes KUPAS Seirama with a business unit oriented to trade services, agricultural services, savings and loans, and food storage. In order to help explore and increase the potential source of village income, BUMDes Pawindan collects savings at the local scale of the village community, including through the management of revolving funds and savings and loans. BUM Desa Pawindan is not solely oriented to business aspects to seek financial benefits but is also oriented to support the improvement of the welfare of the pre-prosperous community in Pawindan village. BUMDesa Pawindan Kupas Seirama (Waste Management Business Group with the motto of Prosperous, Faith, Friendly and Independent) was established in Pawindan Village on October 1, 2015, based in the government office of Pawindan Village, Ciamis District. The working area of BUM Pawindan Village covers the entire area of Pawindan Village, Ciamis District, Ciamis Regency. The vision of BUMDesa Pawindan is:

"Realizing the welfare of the Pawindan village community through the development of economic enterprises and social services with a Motto: (Prosperous, Faithful, Friendly and Independent)".

The mission of BUMDesa Pawindan is:

"Develop BUM Desa as the economic locomotive of the Pawindan Village community".

This maggot group originated from vocational training organized by the BKM Community Association of Pawindan villagers through the KOTAKU program to conduct a comparative study to the Depok area regarding waste management and maggot 
Page 520- 528 ISBN: 978-602-6 988-75-1

Web Jurnal Online: jurnal.unmuhjember.ac.id By: Endah Vestikowati; R. Rindu Garvera; Ii Sujai Sinergity Of The Village Private Business Agency (Bumdes) "Kupas Seirama" On The Improvement Of Village Community Welfare

cultivation. Therefore, the residents of Pawindan village ventured to develop the waste management activities and cultivation of the maggot. Maggot is taken from the word maggot or maggot, the larvae of flies that grow on decaying organic matter such as damaged carcasses, fruit or vegetables.

The activities of the maggot volunteer group consisting of three (3) types, namely:

a. Management of inorganic waste through a waste bank;

b. Management of organic waste, which is leftover food from households such as leftover rice and vegetables; and

c. Cultivation of black flies or maggots which have high protein content which is around $43 \%$ if they are intact, whereas if used as a pellet of protein content between $30-40 \%$ which can be used as animal feed or fish.

The maggot larvae eat almost all types of organic matter such as decaying fruits and vegetables, coffee and tea pulp, rice mill waste, internal organs of fish, animal carcasses, even animal waste, so Maggot is ideal for being used as organic waste processing and compost processors. The benefits of Maggot are as follows:

a. Made as pellets and feed

In addition to being used as pellets, Maggots can also be mixed with ungags such as swans, chickens, ducks, ducks and so on. By directly mixing the concentrate to add protein to $40 \%$ it is very good for its weight growth.

b. Save on feed costs

When we throw away the leftovers without realizing it the next day it has turned into a fat maggot and is ready to be given to our animals. Maggots are available abundantly around us and obviously, do not have to incur additional expensive costs.

c. Made as fertilizer

The end result of maggot leftovers is high-quality fertilizer that can be directly used without needing to be processed again.

Regulation of the Minister of Environment of the Republic of Indonesia Number 12 of 2012 concerning Guidelines for Implementing Reduce, Reuse and Recycle Through Waste Banks that garbage banks are places for selecting and collecting garbage that can be recycled or reused that have economic value. The benefits of garbage banks generally create a clean, healthy, beautiful and unpretentious environment. And this has been done by the village government.

\section{VILLAGE COMMUNITY}

Village communities as part of the object of national development where it aims to create prosperity in the countryside. For this reason, the community is encouraged to create and innovate in creating a sustainable local economy. In addition, the need to realize democratization in the village needs active participation from the community, so that the village government will be transparent and accountable. One of them that can be developed is resource exploration and utilization of human resources in rural areas to be able to solve public problems, especially in the economic sector. Some contexts that can 
Page 520- 528 ISBN: 978-602-6 988-75-1

Web Jurnal Online: jurnal.unmuhjember.ac.id

By: Endah Vestikowati; R. Rindu Garvera; Ii Sujai

Sinergity Of The Village Private Business Agency (Bumdes) "Kupas Seirama" On The

Improvement Of Village Community Welfare

be adopted in developing more advanced, superior and prosperous villages are smart governance, smart economy, smart mobility, smart environment, smart people, smart living and smart tourism (Anang DS, et al 2019: 11). Of the seven conceptions, one is the catalyst in the welfare of rural communities, namely smart economy, where there are several indicators in smart economy, namely innovation, and entrepreneurship that can support the welfare of rural communities.A smart economy consists of innovation and entrepreneurship. Innovation is divided into a spirit of innovation, transformation ability and the existence of funds for the development of a reset or research. In addition, the entrepreneurial spirit also needs to be applied by rural communities so that they will increase productivity and have an impact on the labor market that is more flexible. This will certainly have an effect on the economic stretch of the village community which is more empowered and competitive and reduces the existing unemployment rate in the countryside.The key to success that can be developed in rural areas is social entrepreneurship. According to Hulgard (Hardi.U, 2104) states that there are four main elements in social entrepreneurship, namely social value, civil society, innovation, economic activity. Social value is the most distinctive element of social entrepreneurship. Where it creates tangible social benefits for the community and the surrounding environment. This means that with social entrepreneurship, the community certainly must have a sense of empathy and also be able to maintain the environment, as well as utilize natural resources wisely and wisely.

The entrepreneurship built in rural communities must come from initiatives from the community and the involvement of village communities in efforts to improve social welfare. Innovation is also a determining factor and supporter in the field of entrepreneurship which certainly ignores existing local wisdom and still adheres to the norms of customs that are recognized by the community. This can be done by combining local wisdom and social innovation in creating innovative ideas and ideas in order to advance rural communities. It is also not far from economic activities carried out by the community and balanced with social activities to ensure the sustainability of the economic activities of rural communities.

Entrepreneurship in rural communities is one way of alleviating poverty and income inequality. According to Nur Firdaus, 2014 states that poverty and income inequality are social problems that must be addressed and want to be a shared responsibility, both government, private sector and civil society organizations. It is all comprehensive in order to spur the economic growth of the community and increase the ability of the village community to manage resources and gain more access.

Rural poverty alleviation programs must, of course, rely on creativity and initiatives from rural communities. Government efforts have also been carried out mentoring, guidance, and implementing superior programs in managing poverty. But in reality, these programs have not been able to reduce poverty at the rural level. So one solution is to develop entrepreneurship in rural communities. This is in line with the opinion of Abdul Malik and Sungkowo M (2017) stating that the development of entrepreneurship aims to improve the economy of the poor through empowerment. 
Entrepreneurship development can be a reference that rural communities can have innovative, strong and global-minded characters.

So the key to improving the welfare of rural communities is community empowerment and this can be shaped by learning entrepreneurship, the existence of entrepreneurial incubators and entrepreneurial centers. Entrepreneurship learning aims to increase the knowledge of rural communities in the field of entrepreneurship that is pursued and this is expected to increase the motivation of rural communities in the economic field. In addition, incubators and entrepreneurial centers aim to increase the number of sales of products produced and are centralized in order to create creative economic equality in the village community.

\section{CONCEPT OF WELFARE}

Social welfare and the community as indicators of the success of development in the countryside are the main benchmarks in the success of a development. Social capital as a vehicle for achieving social welfare should not only be a routine activity for residents but also must be able to accommodate various problems and do problem-solving.

BKKBN (in Heri.B et al., 2013) conceptualized the development of village community welfare as a measure of family welfare/community standard of living, consisting of 5 (five) levels of welfare, namely: 1). Poor families; namely families who have not been able to meet minimum basic needs such as food, clothing, shelter and health needs. 2). Prosperous Family I, which is a family that has been able to meet minimum basic needs, but has not been able to fulfill all of its social-psychological needs such as education, family interaction, interaction with the living environment, and transportation. 3). Prosperous Family II, which is a family which in addition has been able to fulfill minimum basic needs, as well as their social-psychological needs, but has not been able to meet the evolving needs of development such as saving, obtaining information, transportation, and so on. 4). Prosperous Family III, which is a family that has been able to fulfill all minimum basic needs, psychological social needs, and development needs, but has not been able to participate maximally towards the community in the form of material, financial contributions, actively participating in social activities, etc. 5). Prosperous Family III-Plus, which is a family that has been able to fulfill all of its needs, both minimum basic needs, psychological social needs, as well as developmental ones and has been able to make a real and sustainable contribution to society or development.

If further studied on welfare measurement indicators by the BKKBN mentioned above, it can be seen that the concept basically includes the components of welfare measurement described earlier, which include components such as: (1) the ability to fulfill minimum basic needs such as food, clothing, shelter and health, (2) the ability to meet socio-psychological needs such as education, social interaction, both in the family environment, community environment, and in the work environment; (3) ability to meet development needs such as saving/investing, obtaining information and so on; (4) the ability to contribute or participate in community social activities. 
Page 520- 528 ISBN: 978-602-6 988-75-1

Web Jurnal Online: jurnal.unmuhjember.ac.id By: Endah Vestikowati; R. Rindu Garvera; Ii Sujai Sinergity Of The Village Private Business Agency (Bumdes) "Kupas Seirama" On The Improvement Of Village Community Welfare

According to Budhi, Cahyono et al (2012) states that the level of welfare and poverty reduction can be done not only through economic empowerment, but also through strengthening social capital, and community development. Social strengthening can be done by developing schemes for strengthening social capital, such as improving the functions of the BPD, LKMD, Gapoktan, PKK, BUMDes, and Cooperatives. The social strengthening of capital is carried out by maximizing the role of social institutions by focusing on strengthening aspects of trust, mutual respect, and mutual benefits, and paying attention to cultural factors and prevailing values.

The core dimension of social capital lies in how the ability of the people (nation) to work together to build a network to achieve a common goal, where this collaboration is characterized by an interrelated pattern that has reciprocal and mutually beneficial impacts and is built on trust supported by norms and positive and strong social values. The strength of this collaboration will be maximized if it is supported by a proactive spirit of making connections over the principles of participatory attitudes, caring attitude, giving and receiving, trusting each other, and reinforced by the values and norms that support it. The implication is that there needs to be a diversity of programs which prioritize the improvement of human capital and social capital capabilities. The implications for entrepreneurship in business activities can be done by creating a situation and conditioning that human capital and social capital support each other on productivity and welfare. Efforts to improve the welfare of rural communities through optimization of social capital should be supported by transformational leadership that is able to influence community members through changing the status quo, increasing individual creativity, providing inspiration and motivation, and having idealism. Social capital should also be supported by human capital that is able to provide innovations for community members.

\section{METHODOLOGY}

In this study, the BUMDes program was innovated, especially related to improving the welfare of the village community through the management of the Seirama Peel Waste Bank. The object of this research is the Seirama Peel BUMDes in the Pawindan Village area with a qualitative descriptive approach. According to Erickson (in Albito. A and Johan. S, 2018: 7), states, that qualitative research seeks to find and describe narratively the activities carried out and the impact of actions taken on their lives. So that this study uses data collection techniques by means of literature studies, observation or observation and documentation.

\section{RESULTS AND DISCUSSION}

Welfare is an ideal, hope and indicator of progress and can also be said as an indicator of the progress of an area as well as rural communities dominated by poor people who are able to improve welfare based on the popular economy. This was implemented in the Kupas Seirama BumDes program which was oriented towards empowering the Pawindan village community. There are several programs implemented by the Seirama Peel BUMDes where the most dominant is the management of waste banks. Where the waste bank focuses on overcoming organic and inorganic waste, it also 
makes Seirama Peel BUMDes still exist and can help the community to improve welfare. The waste bank has benefits for the village community as well as the surrounding environment. In addition, according to the public's view that the garbage bank has a high economic value, the waste bank can benefit and become a participant for the Pawindan village community. People will also get money in the form of money when they exchange their rubbish at the Kupas Seirama garbage bank. The most interesting thing is that the community is not only getting money but can get basic necessities as part of the holiday allowance.

Then there is the problem of organic waste in Pawindan village, which also makes the Kupas Seirama garbage bank under the program implemented by Pawindan village BUMDes. The innovation carried out by the BUMDes is processing organic waste using maggot. The results obtained in the form of compost that can be used as fertilizer and of course maggot larvae that can be used as animal feed and fish. This has an impact on the reduction of organic waste generated from the Pawindan village community.

\section{CONCLUSION}

Based on these studies, the "Peeling Together" BUMDes shows that 1) "Peel Seirama" BUMDes are focused on integrated waste management and have high economic value. , 3) "Renovated Peel" BUMDes have become a driver in providing labor-based employment. 4) BUMDes "Rhythmic Peel" has succeeded in increasing the village's original income. 
Page 520- 528 ISBN: 978-602-6 988-75-1

Web Jurnal Online: jurnal.unmuhjember.ac.id By: Endah Vestikowati; R. Rindu Garvera; Ii Sujai Sinergity Of The Village Private Business Agency (Bumdes) "Kupas Seirama" On The Improvement Of Village Community Welfare

\section{REFERENCES}

Albito. A dan Johan. S. 2018. Metodologi Penelitian Kualitatif. Sukabumi: CV. Jejak.

Anang D.S Dkk. 2019. Desa Cerdas: Transformasi Kebijakan dan Pembangunan Desa merespon era Revolusi Industri 4.0. Yogyakarta, Center For Digital Society UGM.

Hardi. U. 2014. Menumbuhkan Minat Kewirausahaan Sosial. Jurnal Ilmiah Among Makarti. 7.(14).1-16.

Nur Firdaus. 2014. Pengentasan Kemiskinan Melalui Pendekatan Kewirausahaan Sosial. Jurnal Ekonomi dan Pembangunan. 22.(1).55-67.

Abdul Malik dan Sungkowo M. 2017. Pengembangan Kewirausahaan berbasis potensi Lokal melalui Pemberdayaan Masyarakat. Jurnal Of Nonformal Education and Community Empowerment.1.(1).87-10.

Heri R.B. Dkk. 2013. Hubungan Efektivitas Pengelolaan Program Raskin dengan Peningkatan Kesejahteraan Masyarakat di Desa Mamahan Kecamatan Gemeh kabupaten Kepalauan Talaud. Journal Acta Diurna.1.(4).

Budhi Cahyono . dkk, 2012. Peran Modal Sosial dalam Peningkatan Kesejahteraan Masyarakat Petani Tembakau di Kabupaten Wonosobo. CBAM-FE NISSULA.1.(1). 